\title{
Parkinson disease and Neuroleptic withdrawal
}

\author{
Stephen Jambunathan*, Jesjeet Gil, Ong Hui Koh, Hatim Sulaiman \\ From $1^{\text {st }}$ International Congress on Neurobiology and Clinical Psychopharmacology and European \\ Psychiatric Association Conference on Treatment Guidance \\ Thessaloniki, Greece. 19-22 November 2009
}

\section{Background}

Abrupt cessation of most psychiatric drugs leads to varying withdrawal symptoms. Although Clozapine withdrawal symptoms are well documented, this case presentation addresses issues pertaining to the severity of the withdrawals and the similarities to Neuroleptic Malignant Syndrome (NMS). This patient who was only on $100 \mathrm{mg}$ of Clozapine required ventilation in Intensive care unit. Neurologist found no causative factor but treated the patient symptomatically to recovery. Family history however revealed that both the patient's parents suffered from severe Parkinson disease. This case presentation discusses the association between NMS like symptoms and neuroleptic withdrawal syndrome in patients with a family history of Parkinson disease.

\section{Materials and methods}

Case study

\section{Results}

Patient with a strong family history of Parkinson disease are at a greater risk of developing NMS like symptoms when Clozapine is abruptly withdrawn.

\section{Conclusions}

Clozapine and other medications with strong anticholinergic properties should never be abruptly stopped. This fact should be even more important if a patient has a family history of Parkinson disease.

Submit your next manuscript to BioMed Central and take full advantage of:

- Convenient online submission

- Thorough peer review

- No space constraints or color figure charges

- Immediate publication on acceptance

- Inclusion in PubMed, CAS, Scopus and Google Scholar

- Research which is freely available for redistribution 